J. Product. \& Dev., 12(2): $401-410$ ( 2007)

\title{
GERMINATION OF BUTIA PALM SEEDS AS AFFECTED BY PRE- GERMINATION TREATMENTS
}

\author{
S.M. Shahin ${ }^{1}$ and Azza M.S. Arafa ${ }^{2}$ \\ ${ }^{1}$ Botanical Garden Res. Department, Hort. Res. Inst, A.R.C., Giza, Egypt. \\ ${ }^{2}$ Ornamental Horticulture Department, Faculty of Agric., Cairo Univ., Egypt.
}

\begin{abstract}
A study was conducted under plastic house at Orman Botanical Garden, Giza, Egypt during 2005 and 2006 seasons to overcome the deep dormancy state of mature and depulped Butia capitata, (Mart) Mecc, seeds, which may refer to impermeable sclera-endocarp, as well as producing high quality seedlings.

The obtained results indicated that the treatments of soaking in tap water and mechanical scarification slightly improved germination traits and seedling quality, but didn't affect thickness, strength and chemical constituents of scleraendocarp. On the other hand, acid scarification with concentrated $\mathrm{H}_{2} \mathrm{SO}_{4}$, specially for 4 and 6 hrs., significantly improved germination\%, germination velocity, mean germination rate, germination rate index, vigour index and quality of the produced seedlings (assessed as seedling height, root length, root branchlets /seedling and fresh and dry weights of aerial parts and roots), with the superiority of soaking for 6 hrs., treatment, which also reduced thickness, strength and chemical components of endocarp to the minimum values comparing with control and other treatments.

Therefore, soaking the depulped seeds of Butia capitata, (Mart.) Becc., in concentrated sulfuric acid for 6 hrs., can be recommended to farmers as a simple, cheap and very effective way for high and accelerated germination.
\end{abstract}

Key words: Germination, Butia capitata, sulfuric acid $\left(\mathrm{H}_{2} \mathrm{SO}_{4}\right)$, mechanical scarification, endocarp.

\section{INTRODUCTION}

Butia capitata, (Mart.) Becc.; Yatay palm, jelly palm, pindo palm or butia palm (Fam. Palmaceae) is a small to large, solitary, armed or unarmed, monoecious palm, Carries 1-3 seeded fruits with smooth epicarp, thin to thick (pulpy) mesocarp, sometimes sweet and thick, and bony endocarp. Mesocarp is edible and can be made into James. Several species are widespread as slow growing cold-tolerant ornamentals (Natalie and Dransfield, 1987). Doughty et al.(1992) emphasized that B. capitata is the most reliable palm for planting in the New Orleans area, which was considered the most sever 
advective freeze of this century for 10 months of a year, in addition, Garcia et al., (1995) mentioned that cylindrin and lupeo! methyl ether were isolated for the first time from $B$. capitata leaf epicuticular waxes.

Germination of hard- coated Butia seeds was investigated by Broschat (1998) who found that germination rate was significantly improved by removing the thick, hard endocarp from $B$. capitata fruits (134 seedlings/100 endocarps, compared with only 0.8 seedlings /100 endocarps for endocarps planted intact, the seed is polyembryonic). Time to $50 \%$ of final germination rate was not affected by endocarp removal. After-ripening storage did not improve germination rate or time. Germination at $40{ }^{\circ} \mathrm{C}$ was superior to that at $34{ }^{\circ} \mathrm{C}$.

On other plant species, several reports were also recorded by Daquinta et al., (1996) who pointed out that scarification with sulfuric acid (96\%) for $30 \mathrm{~min}$., gave $90 \%$ germination after 30 days in seeds of Chamaedorea seifrizii. Similarly were the results of Gomaa (1998) on Acacia nioltica, Cassia didymobotrya, Terminalia arjuna and Tipuana speciosa, Nofal et al.,(2000) on Pterocarpus delbergoides and Shahin and El-Shakhs (2001) who revealed that soaking Nelumbium nucifera seeds in concentrated $\mathrm{H}_{2} \mathrm{SO}_{4}$ for 6 hrs., significantly improved germination $\%$, germination velocity, mean germination rate, germination rate index and vigour index, but reduced the thickness, strength and chemical constituents of the very hard seed coat to a minimum value with improving seedling quality. Beigh et al., (2002) reported that scarifying the seeds of Aconitum heterophyllum, a medicinal plant of Himalaya, mechanically or chemically with concentrated sulfuric acid increased germination\% and seedling survival and quality. On Atropa acuminata, Ibrar and Hussain (2002) stated that exposure of the seeds to $50 \%$ or concentrated $\mathrm{H}_{2} \mathrm{SO}_{4}$ for 75 seconds raised germination \% up to $78 \%$. Likewise, Voronkova and Kholina (2003) indicated that seeds of Sophora flavescens germinated after dormancy breaking by exposure to concentrated $\mathrm{H}_{2} \mathrm{SO}_{4}$ for 30 (76\%), 45 (87\%) and $60 \mathrm{~min}(83 \%)$.

Recent findings were also pointed out by Olmez et al., (2004) on Capparis ovata, Pascual et al. (2004) on Capparis spinosa, and Gbadamosi and Oni (2004) on the medicinal plant, Enantia chlorantha.

Such study aims to secure the most appropriate treatment to induce the highest and fastest germination for Butia seeds to produce the best quality seedlings.

\section{MATERIALS AMD METHODS}

A trial was undertaken throughout 2005 and 2006 seasons at Orman Botanical Garden, Giza, Egypt to study the effect of some pre-germination treatments on germination characters, sclera-endocarp constituents and quality of Butia palm seedlings.

The fruits of Butia capitata, (Mart.) Becc., were collected at maturity stage from a goodbuilt mother tree during August. Exo-and fleshy meso-carps were peeled by hand (depulping) to get the seeds with the bare, bony endocarps. The bare seeds (mean weight 
of 100 seeds: $77.8 \mathrm{~g}$ ) were then preserved in paper bags at ambient temperature until April, $1^{\text {st }}$ for the two seasons, as they were surface sterilized with $10 \%$ solution of sodium hypochlorite for 10-min., then rinsed several times with sterile distilled water and submitted to the following treatments:

1 -Control; as the seeds received no treatment.

2 - Soaking in tap water for 72 hours.

3-Mechanical scarification (for 3 minutes) by rasp the distal round end of sclera-endocarp (facing the placental end) with a file.

4 - Mechanical scarification (for 3 minutes) + soaking in tap water for 24 hours.

5 - Soaking in concentrated sulfuric acid $(98.5 \%)$ for 2,4 and 6 hours.

Treated seeds of the various treatments were washed several times with tap water, and were then planted in $30 \mathrm{~cm}$ diameter clay pot filled with $3.5 \mathrm{~kg}$ of an equal mixture of loam and sand $(1: 1, \mathrm{v} / \mathrm{v})$. Each pot contained with 15 seeds, which were regularly distributed on the mixture surface and covered with a thin layer of the same mixture and compressed by hand to ensure the completely intact between the seeds and the soil mixture. The pots were placed in a plastic house under temperature of $36{ }^{\circ} \mathrm{C}$ and relative humidity of $70 \%$, as they were arranged in a completely randomized design (Das and Giri, 1986) with 3 replicates (each replicate was a pot containing 15 seeds). Clearly visible plumule protrusion was used as a criterion for germination.

\section{The following data were recorded:}

Germination percentage using the following equation: G.\% $=$ Total No. germinated seeds /total No. raised seeds X 100, germination velocity (G.V.) as the mean No. days from sowing till germination became constant in the treatment, mean germination rate (M.G.R) as the mean No. days to attain $50 \%$ of the total germination (Odetola, 1987), germination rate index (G.R.I) according to Bartled equation described by Hartmann and Kester (1983), plumule length at germination $(\mathrm{cm})$ and vigour index (V.I.) as indicated by Selvaraju and Selvaraj (1994) in the following equation: V.I. = G.\% X mean length of plumule $(\mathrm{cm})$, recorded at the end of experiment on October, $31^{\text {st }}$. Seedling height $(\mathrm{cm})$, root length $(\mathrm{cm})$, No. root branchlets /seedling and aerial parts and roots fresh and dry weights (g) were also measured. In addition, the following determinations and analysis were conducted on the bony endocarp after treatment the bare seeds in the second season only: Endocarp thickness $(\mathrm{mm})$ was measured at many positions using a steel calipar Endocarp strength $(\mathrm{Kg}$. force) was monitored using an universal testing machine, Tinuis Olsen Testing Mchine Co., Willow Grove, P.A., USA at Mechanical Testing Lab., Fac. Engin; Cairo Univ., as the seeds were supported by fulcrum and force was applied to the midpoint of the seed.

Ash (\%), cellulose (\%), hemicelluloses (\%), lignin (\%) and extractives (\%) as the main constituents of the endocarp determined according to Tappi (1988). 
The data were subjected to analysis of variance and the method of LSD was used to compare between means of treatments (Mead et al., 1993).

\section{RESULTS AND DISCUSSION}

\section{Effect of pre-germination treatments on germination traits:}

Data in Table 1 show that germination \% of Butia seeds was significantly increased due to scarification with concentrated $\mathrm{H}_{2} \mathrm{SO}_{4}$ for 4 and $6 \mathrm{hrs}$., as these treatments raised such parameter in the first season to 65.00 and $100.00 \%$, and in the second one to 62.56 and $100.00 \%$, respectively. Germination percentage, however, was linearly increased with the increase in scarification time. This result is in line with that found by Khan (1997), who reported that increasing the period of scarification with sulfuric acid progressively increased $\mathrm{G} \%$ of Indian rice grass seeds.

The least No. days for G, V. and M.G.R. were also recorded by concentrated $\mathrm{H}_{2} \mathrm{SO}_{4}$; treatment for 4 and 6 hrs. in the two seasons. In general, G.V. and M.G.R. were progressively decreased as the duration time of acid scarification was increased. M.G.R. values for soaking in tap water and mechanical scarification treatments or both in combinations, as well as for control were not calculated in both seasons, because G. \% of them did not reach $50 \%$. This result however coincides with that of Shahin and ElShakhs (2001) who indicated that acid scarification with concentrated $\mathrm{H}_{2} \mathrm{SO}_{4}$ for $6 \mathrm{hrs}$, reduced the number of days required to $50 \%$ germination from 120 days to only one day in Nelumbium nucifera. A similar trend was also gained for the G.R.I., as it was significantly increased due to acid scarification for various times with the superiority of 6 hrs., period, which gave the highest values in the two seasons. The longest plumule of germinated seeds was found to refer to soaking in concentrated $\mathrm{H}_{2} \mathrm{SO}_{4}$; for $6 \mathrm{hrs}$. treatment, which increased this trait to 1.03 and $0.93 \mathrm{~cm}$ in the first and second seasons, respectively, whilst mechanical scarification + soaking in tap water for $24 \mathrm{~h}$ treatment significantly raised such trait in the second season only to $0.83 \mathrm{~cm}$. Owing to increment of both germination percentage and plumule length, the vigour index (V.I.) as a real indicator for germination flush was increased to reach the highest and significant means when seeds were soaked in concentrated $\mathrm{H}_{2} \mathrm{SO}_{4}$ for 4 or $6 \mathrm{hrs}$., registering 54.88 and 103.00 in the first season, and 43.17 and 93.00 in the second one, respectively.

According to the aforementioned data, it is clear that soaking in concentrated sulfuric acid for $6 \mathrm{hrs}$. gave the best results because of its ability to reduce the thickness and strength of the very hard endocarp, as shown in Table 3, and this consequently, permits the ease permeability of water and gases across such weakened and softened endocarp, which finally resulted in swelling of the seed, rupture of the endocarp and emergence of the plumule. These results are in accordance with those attained by Daquinta et al.(1996) on Chamaedorea seifrizii, Gomaa (1998) on Acacia nilotica, Cassia djdymobotrya, Terminalia arjuna and Tipuana speciosa, Nofal et al.(2000) on 
Pterocarpus delbergoides, Ibrar and Hussain (2002) on Atropa acuminata and Gbadamosi and Oni (2004) who postulated that germination of Enantia chlorantha seeds was first observed among those seeds treated with concentrated sulfuric acid for 10 minutes 23 days Table 1: Effect of some pre-germination treatments on some germination traits of Butia capitata (Mart) Becc., seeds during 2005 and 2006 seasons.

\begin{tabular}{|c|c|c|c|c|c|c|}
\hline $\begin{array}{l}\text { Pre-germination } \\
\text { Treatments }\end{array}$ & G.\% & $\begin{array}{l}\text { G.V. } \\
\text { (day) }\end{array}$ & $\begin{array}{l}\text { M.G.R. } \\
\text { (days) }\end{array}$ & G.R.I. & $\begin{array}{c}\text { Plumule } \\
\text { length } \\
(\mathrm{cm}) \\
\end{array}$ & V.I. \\
\hline \multicolumn{7}{|c|}{2005} \\
\hline Control & 16.67 & 185.00 & -- & 0.33 & 0.54 & 9.00 \\
\hline Soaking in tap water for $72 \mathrm{hrs}$. & 16.67 & 179.00 & -- & 0.33 & 0.60 & 10.00 \\
\hline Mechanical scarification. & 20.00 & 155.00 & -- & 0.42 & 0.58 & 11.60 \\
\hline $\begin{array}{l}\text { Mechanical scarification } \\
+ \text { Soaking in tap water for } 24 \mathrm{hrs} \text {. }\end{array}$ & 33.00 & 112.00 & -- & 0.50 & 0.77 & 25.41 \\
\hline Soaking in concentrated 2 hrs. & 50.00 & 70.67 & 70.67 & 0.63 & 0.50 & 25.00 \\
\hline $\mathrm{H}_{2} \mathrm{SO}_{4}$ for & 65.00 & 63.33 & 44.33 & 0.72 & 0.84 & 54.88 \\
\hline 6 hrs. & 100.00 & 55.76 & 40.00 & 1.00 & 1.03 & 103.00 \\
\hline L.S.D at 5\% & 35.26 & 115.50 & 28.34 & 0.27 & 0.30 & 21.63 \\
\hline \multicolumn{7}{|c|}{2006} \\
\hline Control & 16.67 & 196.00 & -- & 0.33 & 0.46 & 7.67 \\
\hline Soaking in tap water for $72 \mathrm{hrs}$. & 16.67 & 186.00 & -- & 0.33 & 0.60 & 10.00 \\
\hline Mechanical scarification. & 22.25 & 148.67 & -- & 0.45 & 0.67 & 14.91 \\
\hline \multicolumn{7}{|l|}{ + Soaking in tap water for $24 \mathrm{hrs}$. } \\
\hline Soaking in concentrated $2 \mathrm{hrs}$. & 50.00 & 71.26 & 71.26 & 0.58 & 0.58 & 29.00 \\
\hline $\mathrm{H}_{2} \mathrm{SO}_{4}$ for & 62.56 & 65.18 & 45.67 & 0.70 & 0.69 & 43.17 \\
\hline 6 hrs. & 100.00 & 55.00 & 38.50 & 1.00 & 0.93 & 93.00 \\
\hline L.S.D at 5\% & 33.76 & 121.64 & 26.10 & 0.21 & 0.32 & 25.33 \\
\hline
\end{tabular}

G. $\%$ : Germination percentage. G.V. : Germination velocity. V. I. : Vig

M.G.R.: Mean germination rate. G.R.I.: Germination rate index.

after sowing, while those treated for 20 and 30 minutes commenced germination after 30 days. Seeds treated for 5 minutes with concentrated $\mathrm{H}_{2} \mathrm{SO}_{4}$ had the highest $\mathrm{G}$. $\%$ of $66 \%$ followed by depulped ones, which had $57 \%$. On the other hand, all treated seeds with concentrated nitric acid and hot water $\left(90^{\circ} \mathrm{C}\right)$ failed to germinate.

\section{B. Effect of pre-germination treatments on seedling growth:}

The results in Table 2 indicate that seedling height, root length, No. root branchlets/seedling and fresh and dry weights of aerial parts and roots were significantly increased in response to soaking in concentrated $\mathrm{H}_{2} \mathrm{SO}_{4}$ for 4 and $6 \mathrm{hrs}$. in most cases of both seasons, with the exception of soaking for $2 \mathrm{hrs}$ treatment, which significantly increased height of seedlings in the first season, and aerial parts and roots fresh and dry weights in the second one. The other treatments, however slightly improved such 
characters with non-significant differences when compared to those of control. In general, the superiority was for the concentrated sulfuric acid for $6 \mathrm{hrs}$., treatment, as it gave the

Tab 2 
highest records and best quality in the produced seedlings comparing with all other treatments.

The previous gains may be due to the main role of sulfuric acid treatment in softening the scleroendocarp of seeds and hence, increasing their ability to absorb more water that leads to increase the activity of indolic compounds and release of the soluble sugars, and that may help to waken the embryo and induce germination. In addition, the precocity of germination in acid treated seeds gave the resulted seedlings the sufficient time for more growth and good quality. Such findings are in harmony with those of Broschat (1998) on Butia capitata, Shahin and El- Shakhs (2001) on Nelumbium nucifera, Beigh et al., (2002) on Aconitum heterophyllum and Olmez et a/., (2004) who stated that the optimum chemical treatment for seed germination and good quality of seedlings in Capparis ovata was obtained by soaking the seeds in $0.2 \% \mathrm{KNO}_{3}$ for $8 \mathrm{hrs}$., after treatment with concentrated $\mathrm{H}_{2} \mathrm{SO}_{4}$ for 20 minutes.

\section{C-Effect of pre-germination treatments on endocarp characteristics:}

Dormancy induction can be quantified in terms of growth potential changes; which are often expressed as embryo growth or germination, and variations in seed coat thickness and strength (Khan, 1997). Strength in general, can be defined as the ability of a material to withstand an applied load (Wulpi, 1985). Such strength, however linearly decreased with the decrement in seed coat thickness (Khan, 1997). In the present study, data in Table 3 clear that most pre-germination treatments slightly decreased endocarp thickness and strength of seeds, whereas soaking in the concentrated sulfuric acid for 4 and $6 \mathrm{hrs}$., caused 44.54 and $68.18 \%$ reduction in the thickness, and 83.28 and $87.00 \%$ reduction in the strength, respectively. Mechanical scarification induced a great reduction in thickness at only the scarified area, which didn't exceed $0.4 \mathrm{~cm}$ diameter, while the rest of endocarp is still thick. On the other hand, soaking in concentrated $\mathrm{H}_{2} \mathrm{SO}_{4}$ had the advantage of reducing the thickness of the endocarp as a whole.

With regard to chemical components of scleroendocarp, data in Table 3 showed that the percentages of ash, cellulose, hemicellulose, and lignin and extractives $\%$ were not affected by soaking in tap water, mechanical scarification or both in the combined treatment, as they gave means closely near together and in the same rank with those of untreated one. However, soaking in concentrated $\mathrm{H}_{2} \mathrm{SO}_{4}$ for different periods markedly declined the percent of ash, cellulose, hemicellulose and lignin, while increased the percent of extractives. The highest reduction in such constituents was due to soaking for 6 hrs., followed by 4 hrs. and then 2 hours. 
Table 3: Endocarp characteristics of Butia capitata (Mart) Becc. seeds as affected by some pro-germination treatments in 2006 season.

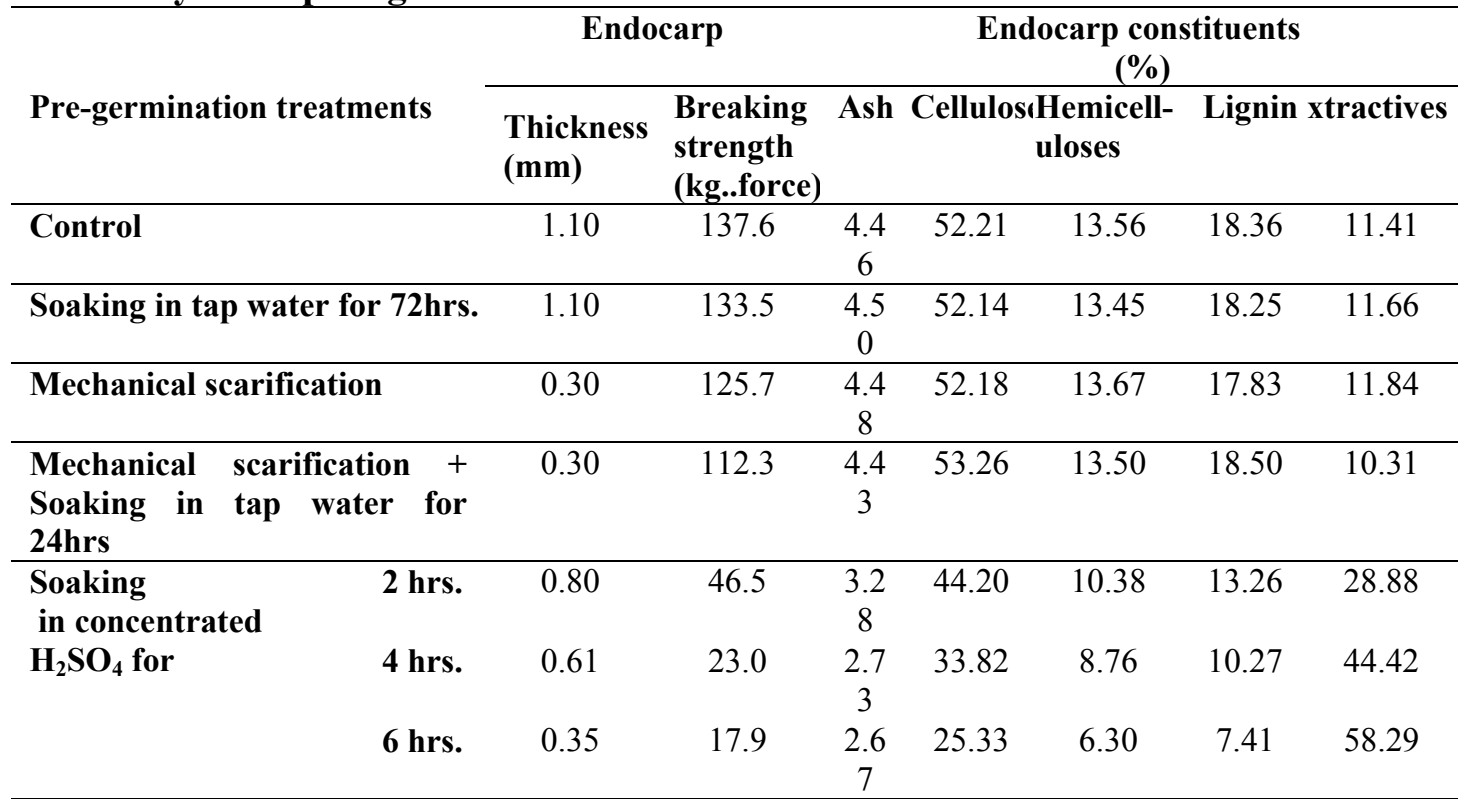

At only the scarified position (about $0.4 \mathrm{~cm}$ diameter).

The aforementioned results obviously indicate the role of soaking seeds in sulfuric acid in softening the very hard endocarp of Butia seeds, through reducing thickness and strength, as well as dissolving the very complicated compounds consisting the seed coat such as cellulose, hemicellulose and lignin to simple and soluble extractives, and that may be the direct reason of elevating germination $\%$ and accelerating germination process. Similarly were those results reported by Shahin and El-Shakhs (2001) on Neluinbo, Voronkova and Kholina (2003) on Sophora flavescens and Pascual et al.,(2004) on Capparis spinosa.

\section{RECOMMENDATION}

According to the previous results, it is recommended to soaking Butia capitata, (Mart) Mecc., depulped seeds in concentrated sulphuric acid for 6 hrs., for best germination and improvement of seedlings quality.

\section{REFERENCES}


Beigh, S.Y.; M. Iqbal and L.A. Nawchoo (2002). Seed germination and seedling survival of Aconitum heterophyllum, an endangered medicinal plant of the North-West Himalaya. Indian J. Plant Physiol, 7(2): 109-113.

Broschat, T.K. (1998). Endocarp removal enhances Butia capitata (Mart.) Becc. (Pindo palm), seed germination. Hort. Technology, 8(4): 536-587.

Daquinta, M; O. Concepcion;I. Capote; I. Cobo; M. Escolona and C. Borroto (1996). In vitro germination of Chamaedorea seifrizii. Principes, 40(2): 112113.

Das, M.N. and N.C. Giri (1986). Design and Analysis of Experiments. $2^{\frac{\text { nd }}{2}}$ Ed., Published by Mohinder Singh Sejwal, for Wiley, New Delhi 110002, 488 pp.

Doughty, S.C.; D.J. Gill and D.C. Blouin (1992). Freeze survival survey of 21 palm species in New Orleans and vicinity. Hort. Technology, 2(4): 460-465.

Garcia, S.; H. Heinzen; C. Hubbuch, R. Martinez; X. De Vries and P. Moyna (1995). Triterpene methyl ethers from Palmae epicuticular waxes. Phytochemistry, 39(6): 1381-1382.

Gbadamosi, A.E. and O. Oni (2004). Effect of pre-treatments on germination of seeds of the medicinal plant Enantia chlorantha Oliv. J. Food, Agric. \& Environ., 2(2): 288-290.

Gomaa, Eman E.A. (1998). Studies on propagation of some ornamental trees. M. Sc. Thesis, Fac. Agric., Kafr El-Sheikh, Tanta Univ., Egypt.

Hartmann, H.T. and D.E. Kester (1983). Plant Propagation, Principles and Practices. Prentice-Hall Inc., Englewood cliffs, New Jersey, 662.

Ibrar, M. and F. Hussain (2002). Germination studies on Atropa acuminata Royle ex Lindley. Pakistan J. Botany, 34 (4): 341-344.

Khan, A. A. (1997). Quantification of seed dormancy: physiological and molecular considerations. Hort. Science, 32(4): 609-614.

Mead, R.; R.N. Curnow and A.M. Harted (1993). Statistical Methods in Agriculture and Experimental Biology. $2^{\text {nd }}$ Ed., Chapman \& Hall Ltd., London, 335.

Natalie, W. and J. Dransfield (1987). Genera Palmarum. Allen Press, Inc., Lawrence, KS 66044, 610.

Nofal, E.M.; A. El-Ashry; E.EI-Mahrouk and A.M. Ali (2000). Physiological studies on propagation of some ornamental trees by seeds. J. agric. Res., Tanta Univ., 26(2): 361-376.

Odetola, J.A. (1987). Studies on seed dormancy, viability and germination in ornamental Palms. Principes, 31 (1): 24-30.

Olmez, Z.; Z. Yahyapglu and A.O. Ucler (2004). Effects of $\mathrm{H}_{2} \mathrm{SO}_{4}, \mathrm{KNO}_{3}$ and $\mathrm{GA}_{3}$ treatments on germination of caper (Capparis ovata Desf.) seeds. Pakistan J. Biological. Sci., 7 (6): 879-882 
Pascual, B.; A. San Bautista; A. Imbernon; S.Lobez; J. Alagarda and J. Manoto (2004). Seeds treatments for improved germination of caper (Capparis spinosa). Seed Science and Technology, 32(2): 637-642.

Selvaraju, P. and J.A. Selvaraj (1994). Effect of pre-sowing treatments on germination and vigour of seed in marigold (Tagetes erecta L). Madras Agric. J., 81(9): 496-497.

Shahin, S.M. and M.H. El-Shakhs (2001). Nelumbo seed germination as affected by some pre-germination treatments. J. Agric. Res., Tanta Univ., 27(1): 179198.

Tappi (1988). T2.03, 204 and 222, Om-88.

Voronkova, N.M. and A.B. Kholina (2003). An influence of temperature factor and scarification of seed germination and growth of Sophora flavescens soland seedlings. Rastitle, nye Resursy, 39(1):43-49.

Wulpi, DJ, (1985). Understanding How Components Fail. Amer. Soc.for Metals, Metals Park, Ohio, 440 73, 51.

\section{إنبات بذور نخيل البوتيا بمعاملات ما قبل الإنبات}

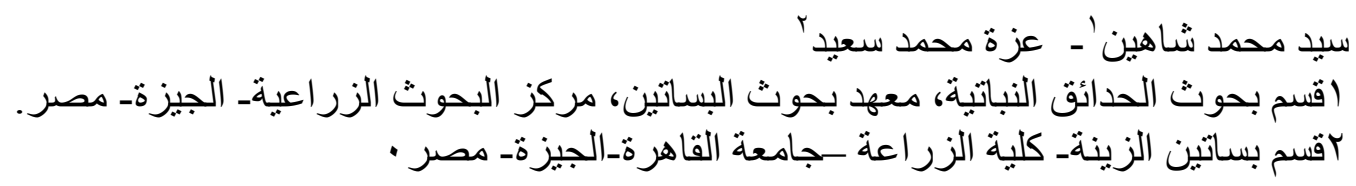

أجريت هذه الدر اسة بأحد الصوبات البلاستيكية بحديقة الأورمان النباتية، الجيزة- مصر خلال الموسمين المتتاليين

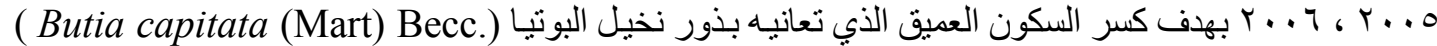

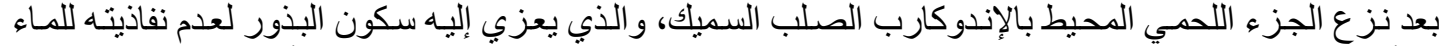

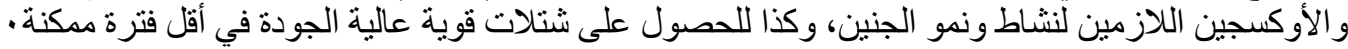

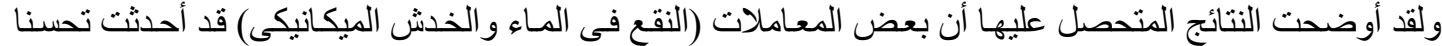

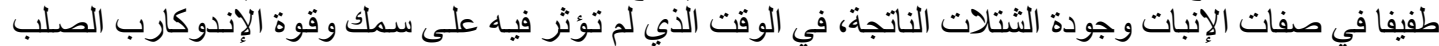
و والمكونات الكيميائية له. اله.

و على الجانب الآخر ، أحدث النقع في حصض الكبريتيك المركز خاصة لمدة (ع أو 7 ساعات) زيادة معنوية في:-

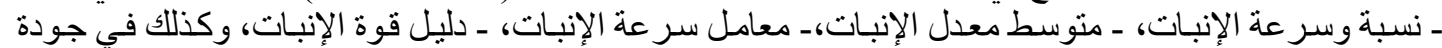

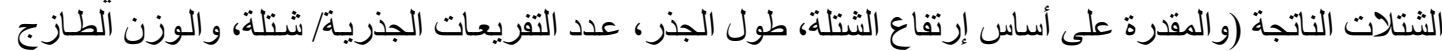
و الجاف للنموات الخضرية و الجفة الجذرية)

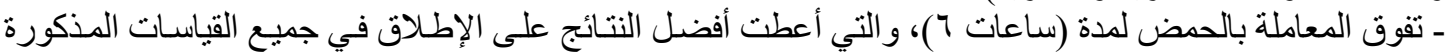

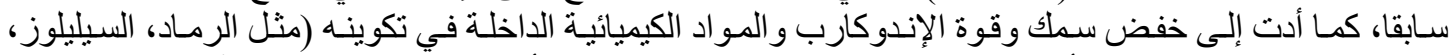

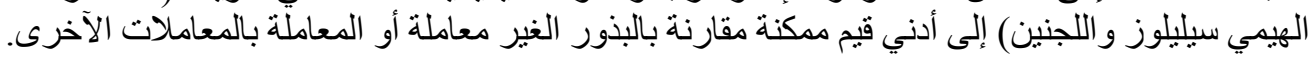




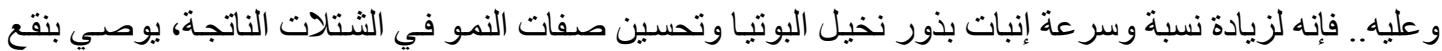

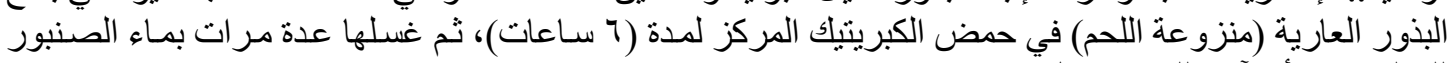
للتخلص من أية آثار للحمض قبل زر العت فتها. 